\title{
Study of Park and Ride Facilities in Cikarang
}

\author{
Annisa $^{1}$, L.B.B Prasetyo ${ }^{1}$ \\ Civil Engineering Department, Technic and Design Faculty, Institute Technology Sains Bandung, Bekasi, Indonesia \\ E-mail: annisa@itsb.ac.id
}

Manuscript Information:
Accepted
12 January 2021
Revised
31 January 2021
Approved
17 February 2021
Published
28 February 2021

Manuscript Information:

12 January 2021

Revised

31 January 202

17 February 2021

28 February 2021

\begin{abstract}
The enormous number of Cawang-Cikarang toll road private vehicles users have caused congestion in Jakarta. To reduce congestion in Jakarta, suburban areas, such as Cikarang, commuters shall utilize Park and Ride $(\mathrm{P} \& \mathrm{R})$ facilities than use private vehicle to Jakarta. This study is important to give the commuters information of $\mathrm{P} \& \mathrm{R}$ in Cikarang, so they can make an option of their trip. P\&R facility has a main function as a hub to change from private vehicle to public transportation. Observation as well as questionnaire were used to reveal findings for this study, the data results are analyzed with descriptive statistics. This study revealed that users of $P \& R$ facilities from Cikarang are generally commuters who have offices in urban areas and reside in suburban areas. The problem that occurs in Cikarang is that parking facilities in transit locations (stations / terminals / stops) have not been utilized optimally. This study aims to analyze the actual state and user satisfaction of $P \& R$ facility in Cikarang. The six locations include: (1) Cikarang Station; (2) Metland Telaga Murni Station; (3) Lemahabang Station; (4) Cikarang Terminal; (5) Capitol Stop; and (6) AO Citywalk Lippo Cikarang Bus Stop. The results showed that the majority of respondents $(\mathrm{N}=231)$ were satisfied $(\mathrm{m}=3.78 ; \mathrm{SD}=0.99, \mathrm{p}<0.001)$ with existing $\mathrm{P} \& \mathrm{R}$ services. In addition, this research also shows that most $P \& R$ facilities in Cikarang are managed independently by local residence.
\end{abstract}

Keywords: park and ride (P\&R); cikarang; commuters; facility

\section{INTRODUCTION}

Indonesia has transportation problems (congestion) especially in metropolitan cities, such as Bandung, Jakarta, and Surabaya (Annisa et al., 2019). The mobility of residents from the satellite city area around the Central Business District (CBD) is one of the factors causing congestion (Sembiring, 2015). In Indonesia, the Special Capital Region (DKI) Jakarta has an area of $662.33 \mathrm{~km}^{2}$ with a population of 10,467,600 inhabitants (BPS, 2019), on weekdays the number increases with workers coming from satellite city areas such as Bogor, Depok, Tangerang, Bekasi (Bodetabek). Congestion in DKI Jakarta itself occurs due to the mobility of Bodetabek residents who use private vehicles to DKI Jakarta (Nazalaputra \& Handayeni, 2017). 
To solve this problem, the DKI Jakarta government has made various policies and traffic engineering as well as transportation infrastructure development in managing the circulation of private vehicles in DKI Jakarta (Suryandari et al., 2015). The Government of DKI Jakarta has been working with the Bodetabek satellite city government to build Park and Ride (P\&R) facilities. P\&R aims to allow travelers to move from private vehicles (motorcycles, cars, bicycles, and other private transportation) to public vehicle (buses, trains, and other rapid mass transportation) originating from the satellite city to the CBD (Annisa et al., 2019; Liu et al., 2020; Nusraningrum \& Isibhi, 2013).

Cikarang is one part of Bekasi regency. Cikarang area consists of five sub-districts, namely Sub-District (1) Central Cikarang, (2) South Cikarang, (3) West Cikarang, (4) East Cikarang and (5) North Cikarang. Cikarang has an area of $247.64 \mathrm{~km} 2$ and has a population of 745,000 (BPS, 2019). In the morning and evening traffic activity from Cikarang is very dense. This travel activity caused congestion on several sections of Bekasi connecting roads with DKI Jakarta, such as the Jakarta-Cikampek Toll Road, Kalimalang arterial section, and the Pantura Line arterial section. The Central Bureau of Statistics (2019) recorded 235,952 class 1 vehicles passing through Cawang-Cikarang Toll Road. The high intensity of class 1 vehicles caused congestion in DKI Jakarta. To reduce congestion in Jakarta one solution is to use P\&R facilities available in suburban areas. Therefore, studies are needed for the P\&R scheme in Cikarang, to be able to provide an overview to private vehicle users to be able to use P\&R facilities. There are six P\&R locations in Cikarang, namely: (1) Cikarang Station, (2) Metland Telaga Murni Station, (3) Lemahabang Station, (4) Cikarang Terminal, (5) Capitol Bus Stop and (6) AO Citywalk Lippo Cikarang Bus Stop. There are two types of transportation modes used from the six P\&R locations in Cikarang, including buses and electric trains (KRL). Both modes of transportation have a variety of schedules and fares.

P\&R has several main facilities and supporting facilities. The main facilities are parking for two-wheeled vehicles and four-wheeled vehicles. Other facilities are supporting facilities, such as: security post, helmet storage, CCTV, canopy, parking availability signs, kiss and ride facilities, subscription rates, parking lines, separation of car and motorcycle entrances, cafeteria facilities, and ATM facilities (Suryandari et al., 2015). The South Yorkshire Passenger Transport Executive (2006) in Palupiningtyas (2015) said the P\&R facility was a vehicle parking area located in a location far from the city center linked to high-frequency transport services. Users of $\mathrm{P} \& \mathrm{R}$ facilities are generally workers in the city center who live in the suburbs (KemenLH, 2009). With this facility they can park the vehicle in the morning for reused in the afternoon. P\&R facility aims to facilitate private vehicle users who continue their journey using public transportation so as to reduce traffic congestion in the city (Palupiningtyas, 2015). In contrast to Bekasi, Jakarta, and Tangerang which already have formal facilities P\&R. Cikarang currently does not have special parking facilities $P \& R$ that has been integrated with public transportation. This is an obstacle in the practice of Cikarang commuter P\&R. 
Parking facilities that exist today are vehicle parking facilities, both in transit locations (stations/ terminals /bus stops) and those in the surrounding community. This P\&R scheme is one of the efforts of Transit Demand Management (TDM). By utilizing the concept of TDM, it will support the concept of sustainable transportation in Cikarang, therefore it is necessary to study the practice of $P \& R$ in Cikarang. This study aims to analyze how the actual state of $P \& R$ facilities and user satisfaction of $P \& R$ facilities in Cikarang to support sustainable transportation in Indonesia.

\section{THEORITICAL FRAMEWORK}

\subsection{Sustainable Transportation}

Sustainable transportation is closely related to sustainable urban development. In developing sustainable transportation in Jakarta, the things to consider are traffic congestion in the surrounding satellite city (Bodetabek) as well as air emission problems caused by such congestion (Asapa, 2014; Dijk et al., 2013; Marshall \& Banister, 2000). In addition to congestion, other important issues caused by transportation activities in the city, namely: (1) air pollution (2) noise pollution; (3) road safety; (4) reduced urban landscape; (5) the use of space due to traffic congestion; and (8) global warming (Banister, 2000). In general, sustainable transportation at least meets requirements such as: (1) can accommodate the basic needs of transportation in terms of safety, comfort, and reliability; (2) can be economically profitable; (3) may provide several choices of modes of transportation; (4) can reduce air pollution by using vehicles with renewable energy and (5) regulate and limit the adverse effects of carbon and air emissions (Gilbert \& Tanguay, 2000).

\subsection{Transit Demand Management (TDM)}

TDM as measures aimed at influencing the intensity, time, and distribution of space from transportation demand to reduce traffic impacts or improve mobility options (FHWA, n.d.). The issue of TDM has improve since the energy crisis and air quality has been a major factor in making regulations in transportation engineering. TDM refers to part of transportation regulations that tries to change the habits of road users to use transportation systems more efficiently. TDM can be combined with other public transit systems or investment in new road plans to make system investment more efficient. In maintaining air quality and environmental factors, the concept of TDM falls within the scope of transportation planning on the grounds of cost effectiveness. TDM can be a new investment in traffic management system that try to influence traffic flow by providing accurate information about current traffic conditions on a variety of travel alternatives (Ferguson, 2018). One of the TDM programs is P\&R.

\subsection{Park and Ride (P\&R)}


$\mathrm{P} \& \mathrm{R}$ is a transportation management where commuters can park their vehicles in a parking lots connected to public transport modes (Asapa, 2014; Shen et al., 2017). P\&R has a remarkably effective strategic level to bridge travelers with private vehicles who want to reach their destination by public transportation. P\&R is also one of the tools in limiting the use of private vehicles in the city center by accommodating parking spaces for low-cost private vehicles and then continuing on to the city center (Nusraningrum \& Isibhi, 2013).

P\&R location is placed in the integrated terminal area or Transit Oriented Demand (TOD) where the traveler then continues the journey by bus or train. P\&R can be placed in satellite/suburban cities or bus terminal or busway shelter. $P \& R$ is a parking facility provided to support the use of public transportation from the city border (Suryandari et al., 2015). Owners of private vehicles in suburban areas that have a destination to the CBD in urban areas can switch modes of transportation to public transport by using P\&R facilities in the suburban area (Indah et al., 2015; Palupiningtyas, 2015; Safitri et al., 2015). P\&R can reduce traffic and environmental issues (Lam et al., 2001; Parkhurst \& Meek, 2014; Vincent, 2007; Ying \& Xiang, 2009).

\subsection{Gap Analysis}

Previous research has discussed a lot about P\&R studies at the level of P\&R facilities that have matured in Indonesia, some of them are (Darmawan \& Riduansyah, 2017; Nazalaputra \& Handayeni, 2017; Palupiningtyas, 2015; Sembiring, 2015; Suryandari et al., 2015). Most of his research examines the issue of integrated formal parking facilities facilitated by the government and devoted to P\&R. There are also several studies at the level of pioneering $\mathrm{P} \& \mathrm{R}$ facilities in Indonesia that already exist in some areas such as Bandung, Palembang, Kendal (Asapa, 2014; Buchari, 2015; Fajar \& Djunaedi, 2020). The research discussed the realization of $\mathrm{P} \& \mathrm{R}$ schemes concept and the potential $\mathrm{P} \& \mathrm{R}$ users in informal facilities around transit locations. Based on the research, the ease of finding parking location is one of the obstacles for commuters to use P\&R facilities. Therefore, this study examines the situation of $P \& R$ facilities in Cikarang and the perception of commuters towards the facility. This is done to get general information about P\&R facilities in Cikarang.

\section{METHODS}

The approach used in this study is a positivistic approach. This type of research is a combination of qualitative and quantitative. This study is an expansive case study. Expansive case studies try to build an understanding of the current P\&R situation in Cikarang based on the theory related to P\&R. To confirm the theory to the current situation, the data collection process involves field observation, literature study and questionnaire.

Observation in the field was conducted as a preliminary survey to find out the location of $\mathrm{P} \& \mathrm{R}$ in Cikarang. Literature studies are used to support theories and concept ideas related to research variables in the preparation of questionnaires. Variables, indicators, and 
parameters are built from journal library reviews and implementations of integrated transportation systems in several countries. The variables used in the questionnaire can be seen in Table 1 (Nazalaputra \& Handayeni, 2017). This variable was chosen to know what factors are considered by commuters in using parking facilities and how commuters perceive existing parking facilities. User satisfaction levels can be seen in section 4.3 are known by providing questionnaires with a likert scale about tangible and intangible facilities. This aims to give a real picture of how P\&R users are satisfied with existing parking facilities to entice commuters to use parking facilities.

Table 1. Research Variable (Source: Author)

\begin{tabular}{|c|c|}
\hline Indicator & Variable \\
\hline \multirow{4}{*}{$\begin{array}{l}\text { Socioeconomic } \\
\text { Characteristics }\end{array}$} & Gender \\
\hline & Age \\
\hline & Job \\
\hline & Income \\
\hline \multirow[t]{9}{*}{ Travel Characteristics } & Origin of departure location \\
\hline & Time to Departure Location \\
\hline & Travel Intent \\
\hline & Mode of Transportation to the departure location \\
\hline & Use of parking facilities at the departure location \\
\hline & $\begin{array}{l}\text { Number of Mode Usage At the location of the stop to the } \\
\text { destination }\end{array}$ \\
\hline & $\begin{array}{l}\text { Types of Public Transportation Modes used at stops to } \\
\text { destinations }\end{array}$ \\
\hline & $\begin{array}{l}\text { Reasons for choosing a mode of public transportation to the } \\
\text { destination }\end{array}$ \\
\hline & Frequency of use of public transportation modes \\
\hline \multirow{5}{*}{$\begin{array}{l}\text { Parking User } \\
\text { Satisfaction } \\
\text { (Tangible and } \\
\text { Intangible facilities) }\end{array}$} & Parking Fee \\
\hline & Parking Management \\
\hline & Parking Services \\
\hline & Parking Convenience \\
\hline & Parking Security \\
\hline
\end{tabular}

The method of collecting data is done by observation or field visit directly to obtain a visual picture with the photo media is also done by interview. Observations were carried out to see the condition of the transit location (station / terminal / stop) observed and the condition of the P\&R facilities at the observation site. The last method of data collection is the dissemination of questionnaires. Sampling technique used are nonprobability sampling i.e., purposive sampling. The target respondents were commuters P\&R users.

The distribution of questionnaires for respondents is done by directly visiting the respondents at the $\mathrm{P} \& \mathrm{R}$ facility, station/terminal/stop (on site visitor). In addition to primary data collection is also caried out with literature studies to obtain theoretical reviews. Secondary data needed in this study in general for supporting data, especially related to urban or metropolitan profiles of DKI Jakarta and Cikarang, public 
transportation condition both infrastructure and operations and parking facilities around the station in general. Statistically descriptive data analysis is used to identify P\&R characteristics in Cikarang. Descriptive statistical analysis technique is the application of statistical methods to collect, process, present, and analyze quantitative data descriptively. To get 231 respondents, a questionnaire with a sample of P\&R users was required at (1) Cikarang Station, (2) Metland Telaga Murni Station, (3) Lemahabang Station, (4) Cikarang Terminal, (5) Capitol Bus Stop and (6) AO Citywalk Lippo Cikarang Bus Stop.

\section{RESULT AND DISCUSSION}

In general, the description of $P \& R$ facilities is mostly semi-permanent building, detail can be seen in section 4.1. Other facilities offered are 24-hour parking and helmet storage. The average parking fee is Rp. 5.000,00 per day. Results shows that most P\&R facilities are privately managed by the local residence and serve two-wheeled vehicles. This is not in line with the P\&R scheme's goal of reducing private car users because there are still few private car users who use $P \& R$. Further explanation of the $P \& R$ characteristics can be seen in section 4.2. This condition is the same as other city P\&R schemes, such as Bandung and Kendal where the condition of public transportation in the city has not been integrated properly. The perception and characteristic of respondents who have used P\&R can be seen in section 4.3 .

\subsection{Observation of P\&R Facilities in Cikarang}

In line with the theory of $P \& R$, the characteristics is a sub urban type where $P \& R$ Cikarang facilities are located $48 \mathrm{~km}$ from the city center (CBD). Another characteristic of $\mathrm{P} \& \mathrm{R}$ has been found to be the intermodal transfer service between private vehicles and public transportation, pedestrians, carpools, vanpools, or shuttles. Public transportation modes that are already in operation are buses and trains (Safitri et al., 2015; Ying \& Xiang, 2009).

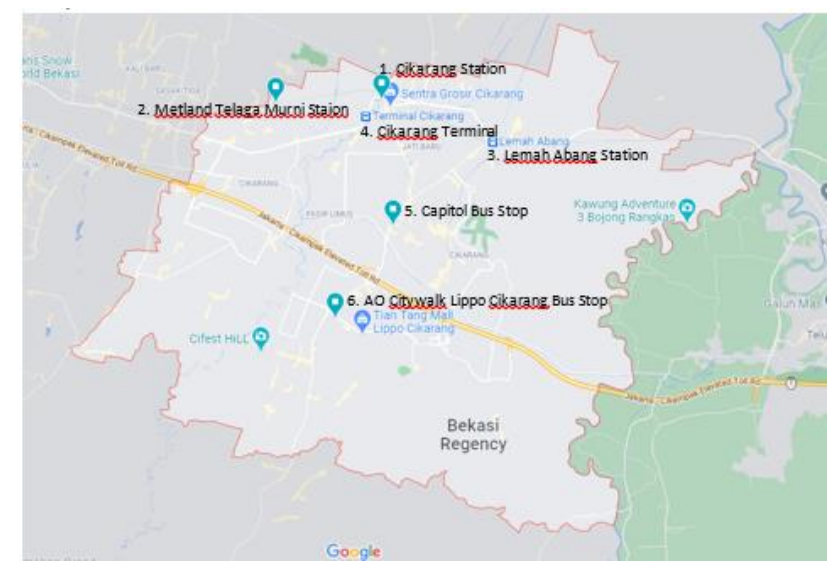

Figure 1. Map of Studi at Cikarang Region, Bekasi, West Java

(Coordinates: -6.3111354449085, 107.15764833390135)

Source: https://goo.gl/maps/pnFjJNSHed1gR9P46 (Accessed: 2021-02-24) 


\subsubsection{Cikarang Station}

Cikarang Station parking facilities are divided into two, namely in front of the station and in the residence of the community around the station. The parking facilities are managed by the community. There are five parking facilities in the community residence around the station. Parking facilities are a 2-5-minute walk away. Supporting facilities are helmet storage, while for toilets, prayer room and waiting area are only available at the station. The applicable parking rate is IDR 5,000 per day. There is no limit to the number of days for one parking. Parking hours are 24 hours. Access to parking facilities can be reached by two-wheeled and four-wheeled vehicles. Parking service is only for twowheeled vehicles only, for parking four-wheeled vehicle are available in the station parking facilities. In addition to the above parking facilities, there is also parking activity on the road to the station. There is a parking attendant to ensure the safety of the vehicle. Some parking spaces come with a fence and a roof. The existing condition of parking facilities at Cikarang Station can be seen in Figure 1.
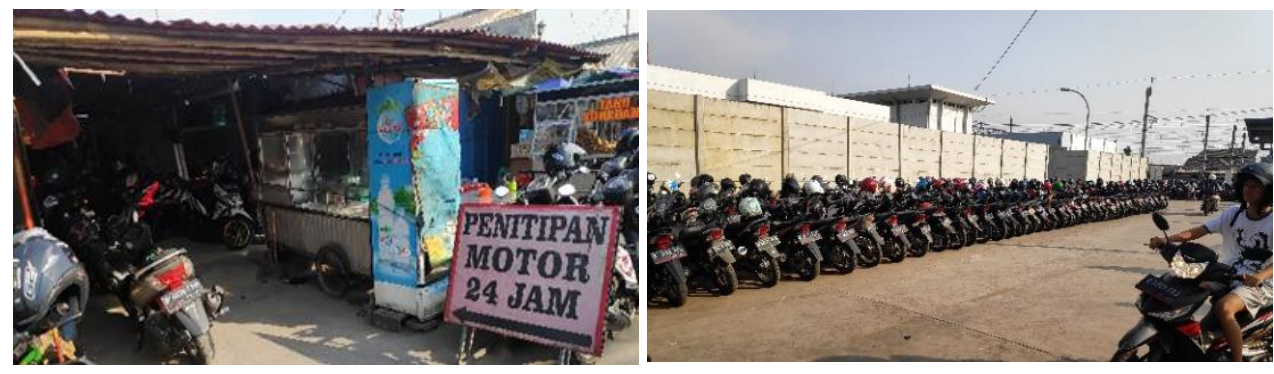

Figure 2. Parking Locations Around Cikarang Station Source: Field Observation (Taken: 2019/10/16)

\subsubsection{Metland Telaga Murni Station}

Parking facilities at Metland Telaga Murni Station are located at Jl. Raya Metland Cibitung and Jl. Wijaya Kusuma III. Both parking facilities are managed by the surrounding community. Parking facilities are a 2-5-minute walk away. There are no other supporting facilities. The applicable parking rate is IDR 5,000 per day. There is no limit to the number of days for one parking. Parking hours are 24 hours. Access to parking facilities can be reached by two-wheeled and four-wheeled vehicles. Parking services for two-wheeled vehicles and four-wheeled vehicles. For four-wheeled vehicle parking is only available at the parking facilities Jl. Raya Metland Cibitung. The existing condition of parking facilities at Metland Telaga Murni Station can be seen in Figure 2. 

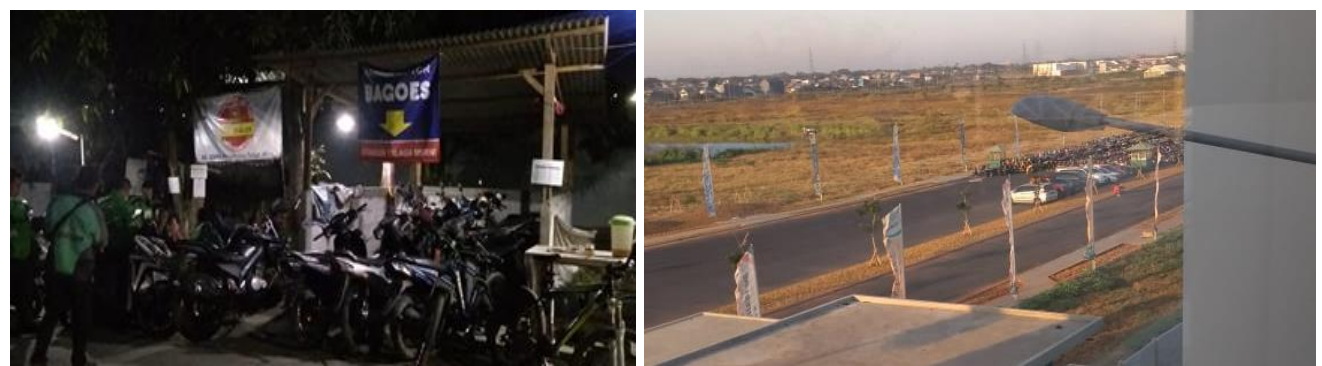

Figure 3. Parking Locations near Metland Telaga Murni Station

Source: Field Observation (Taken: 2019/10/13)

\subsubsection{Lemahabang Station}

The station is equipped with two parking facilities located on Jl. Urip Sumoharjo and Jl. Raya Lemahabang. Both parking facilities are provided by the surrounding community. Parking hours are 24 hours. Lemahabang Station does not provide parking for passengers who will use train transportation, because the area of the station is small enough to be used for parking. The existing condition of parking facilities at Lemahabang Station can be seen in Figure 3.
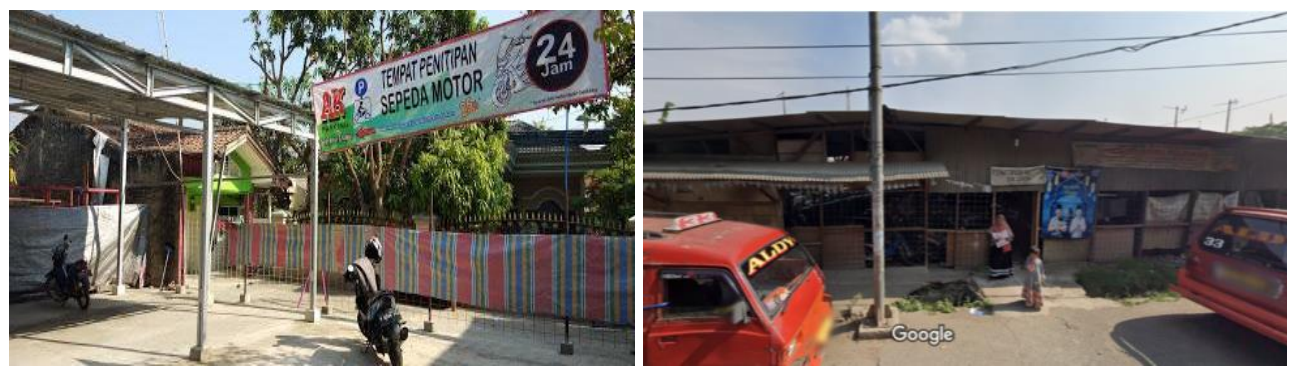

Figure 4. Parking Facilities Around Lemahabang Station

Source: https://www.google.com/earth/ (Accessed: 2021/02/23)

\subsubsection{Cikarang Terminal}

Parking lot in Cikarang Terminal can be used for two-wheeled vehicles and fourwheeled vehicles. The parking lot provided by the terminal is limited that many travelers park their vehicles in parking facilities managed by the surrounding community. The applicable parking rate is IDR 5,000 per day. There is no limit to the number of days for one parking. Public facilities (toilets, prayer rooms, waiting area) at this terminal station are quite complete although there are not maintained. The condition of parking facilities around Cikarang Terminal can be seen in Figure 6 . 

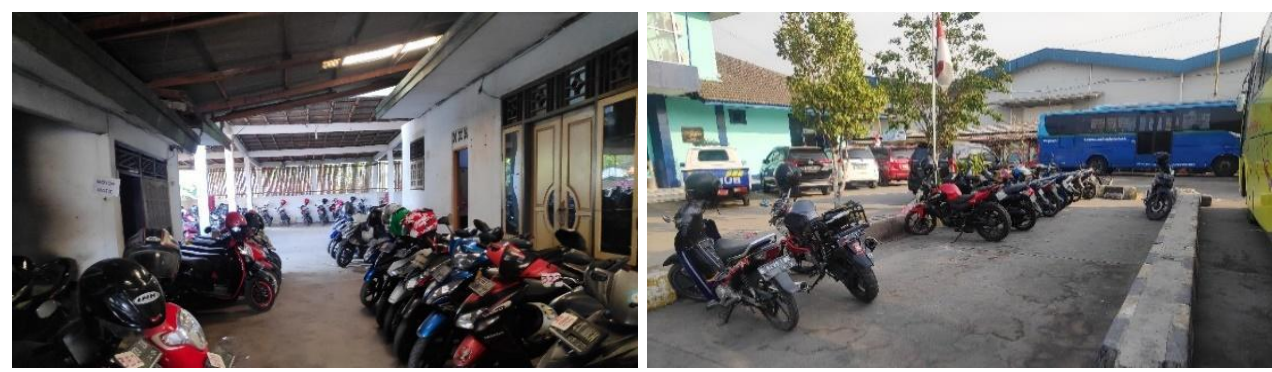

Figure 5. Parking Facilities Around Cikarang Terminal.

Source: Field Observation (Taken: 2019/10/19)

\subsubsection{Capitol Bus Stop}

Capitol Bus Stop is one of the bus stops located in Jababeka area, Cikarang. A few meters before the stop there is a special motorcycle parking lot consisting of two floors with a daily rate of Rp. 5.000,00. This parking lot has several facilities such as: toilet, prayer room, motorcycle wash service, helmet wash service, helmet storage and canteen. This parking lot operates 24 hours and has been established since 2004. The condition of the parking facilities around the Capitol Bus Stop can be seen in Figure 7.
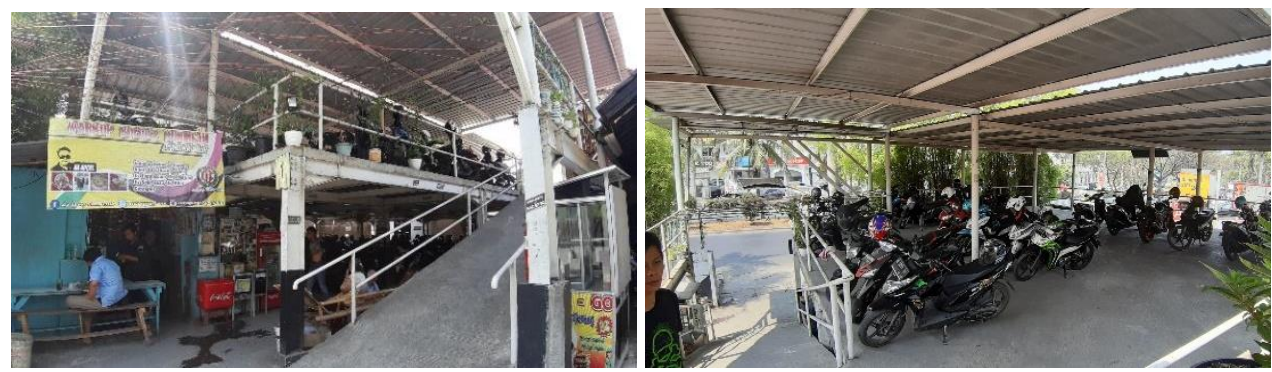

Figure 6. Parking Facilities at Capitol Stop

Source: Field Observation (Taken: 2021/10/16)

\subsubsection{AO Citywalk Lippo Cikarang Bus Stop}

The AO Citywalk Lippo Cikarang Bus Stop is equipped with one bathroom and one nursing room and has a security guard. Shuttle user parking facilities are in Citywalk Lippo Cikarang. The four-wheeled vehicle parking is located just behind the shuttle stop while the motorcycle parking is located behind the Citywalk which is quite far from the shuttle. The location of the parking facilities can be reached 2-5 minutes by foot. The parking lot is quite spacious because it is a parking facility of The Citywalk Lippo Cikarang commercial area. The level of security is guaranteed by the management of official parking managers equipped with CCTV and security officers. The price for two-wheeled vehicle parking ticket per hour is IDR 2.000. The price of four-wheeled vehicle parking ticket per hour is IDR 4,000. The condition of parking facilities around AO Lippo Cikarang Bus Stop can be seen in Figure 8. 

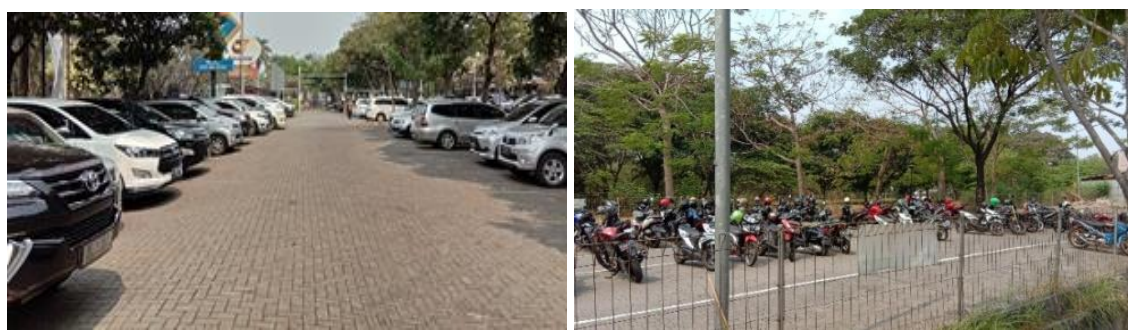

Figure 7. Parking Facilities Around AO Citywalk Lippo Cikarang Bus Stop Source: Field Observation (Taken: 2019/10/14)

\subsection{Characteristics of P\&R Cikarang Facilities}

From table 2 it can be seen P\&R facilities in Cikarang are not special parking spaces for P\&R provided by the government. The facilities are not integrated with public transportation and are not reserved for $P \& R$ users only, unlike $P \& R$ facilities in other location i.e., Bekasi and Jakarta. Based on theory, in general P\&R facilities is planned and specially designed as a complement to public transportation functions. Facts indicates that $\mathrm{P} \& \mathrm{R}$ facility in Cikarang is provided by the community or make use of the shopping parking facilities. However, the P\&R scheme already exists in Cikarang and is commonly known as a 24-hour motorcycle parking lot. Summary of the existing P\&R facilities can be seen in table 2. Based on private mode used by commuters that choosing the scheme of $\mathrm{P} \& \mathrm{R}$ is a user of two-wheeled vehicles, while commuters with four-wheeled vehicles are provided in large-scale transit locations, such as Cikarang Station, Telaga Murni Station, and Cikarang Terminal. Commuters who want to choose P\&R schemes in Cikarang can easily find P\&R facilities at the transit location of Cikarang Station, Telaga Murni Station, and Cikarang Terminal. This is because the transit location is the main location where mass transportation is located. Unlike the P\&R at Cikarang Station and Telaga Murni Station, there are no parking facilities provided at Lemahabang Station because this transit location is a small-scale station.

Table 2. General P\&R characteristics of facilities in Cikarang (Source: Author) General Characteristics Transit Location

\begin{tabular}{ccccccc} 
& $(1)$ & $(2)$ & $(3)$ & $(4)$ & $(5)$ & $(6)$ \\
\hline Exclusively for P\&R & $\mathrm{x}$ & $\mathrm{x}$ & $\mathrm{x}$ & $\mathrm{x}$ & $\mathrm{x}$ & $\mathrm{x}$ \\
\hline Car service & $\mathrm{x}$ & $\sqrt{ }$ & $\mathrm{x}$ & $\mathrm{x}$ & $\mathrm{x}$ & $\sqrt{ }$ \\
\hline Motor service & $\sqrt{ }$ & $\sqrt{ }$ & $\sqrt{ }$ & $\sqrt{ }$ & $\sqrt{ }$ & $\sqrt{ }$ \\
\hline Car access & $\sqrt{ }$ & $\sqrt{ }$ & $\mathrm{x}$ & $\sqrt{ }$ & $\sqrt{ }$ & $\sqrt{ }$ \\
\hline Motor access & $\sqrt{ }$ & $\sqrt{ }$ & $\sqrt{ }$ & $\sqrt{ }$ & $\sqrt{ }$ & $\sqrt{ }$ \\
\hline Supporting facilities & $\sqrt{ }$ & $\sqrt{ }$ & $\mathrm{x}$ & $\sqrt{ }$ & $\sqrt{ }$ & $\sqrt{ }$ \\
\hline Security & $\mathrm{x}$ & $\mathrm{x}$ & $\mathrm{x}$ & $\mathrm{x}$ & $\mathrm{x}$ & $\sqrt{ }$ \\
\hline In a separate location & $\sqrt{ }$ & $\sqrt{ }$ & $\sqrt{ }$ & $\sqrt{ }$ & $\sqrt{ }$ & $\sqrt{ }$ \\
\hline In transit location & $\sqrt{ }$ & $\sqrt{ }$ & $\mathrm{x}$ & $\sqrt{ }$ & $\mathrm{x}$ & $\sqrt{ }$ \\
\hline
\end{tabular}


$\sqrt{ }=$ Available, $x=$ Unavailable

Description: (1) Cikarang Station, (2) Metland Telaga Murni Station, (3) Lemahabang

Station, (4) Cikarang Terminal, (5) Capitol Bus Stop and (6) AO Citywalk Lippo

Cikarang Bus Stop.

\subsection{Characteristics of P\&R User Respondents}

The total number of respondents who participated in this study was $\mathrm{N}=231$. However, the majority of respondents in this study used online transportation when departing from residence to a transit point (Station/Terminal/Bus Stop). In addition to online transportation, respondents also used their personal vehicles and parked the vehicle in the station / terminal / bus stop (in accordance with the concept of P\&R). This study selected respondents limited to $\mathrm{P} \& \mathrm{R}$ facility users. Male respondents $(\mathrm{N}=67, \mathrm{SD}=0.44)$ dominated the study compared to female users $(\mathrm{N}=27, \mathrm{SD}=0.44)$. The majority (99\%) $\mathrm{P} \& \mathrm{R}$ user is a motorcycle user. Respondents have a high level of education; this is indicated by the number of respondents who have been or are studying higher education bachelor's degree. Most of the respondents in this study were middle-class socioeconomic groups, this is shown by monthly income ranging from 4.5 to 7.5 million rupiah. The average satisfaction of respondents to $\mathrm{P} \& \mathrm{R}$ facilities was $3.78(\mathrm{SD}=0.99, \mathrm{p}<0.001)$ on a scale of 5 . This research shows that tangible $(\mathrm{M}=3.73, \mathrm{SD}=0.86, \mathrm{p}<0.001)$ and intangible $(\mathrm{M}=3.76$, $\mathrm{SD}=0.65, \mathrm{p}<0.001)$ facilities are important aspects of $\mathrm{P} \& \mathrm{R}$ facilities. There were $57.8 \%$ of train users compared to $42.2 \%$ of bus users. Train users $(\mathrm{M}=3.75, \mathrm{SD}=0.99, \mathrm{p}<0.001)$ have almost the same level of satisfaction as bus users $(\mathrm{M}=3.82, \mathrm{SD}=0.99, \mathrm{p}<0.001)$.

\section{CONCLUSIONS}

From the result and discussion, it can be concluded that Cikarang already has P\&R facilities. The actual state of $P \& R$ facilities in Cikarang are not a special parking lot provided by the government to support commuters who want to choose the P\&R scheme. Parking facilities available in general are 24-hour motorcycle parking facilities provided by the community around the transit location. There are already car users implementing P\&R schemes at Metland Telaga Murni Station, but the number is still minimal compared to car users who still choose to drive a car to meet its travel destination and this travel option contribute to congestion in Jakarta.

Based on this study, car user commuters have not been interested in the park and ride scheme in Cikarang. Nevertheless, many commuters have implemented P\&R schemes especially motorcycle users. sCommuters who use P\&R facilities have a positive perception of the existing condition of on-site parking facilities. This is indicated by the majority of respondents are satisfied with the existing P\&R services. Based on results of this perception P\&R in Cikarang has a good opportunity if integrated with the government transportation development plan. From this study can be seen that the application of park and ride scheme is a simple concept and get a good response from its users. So that this P\&R scheme can attract car users to support sustainable transportation in Indonesia. 


\section{ACKNOWLEDGMENTS}

Thanks to the Directorate of Research and Community Service for funding this research.

\section{REFERENCES}

1) Annisa, Herman, \& Wiradinata, I. (2019). A sustainable transportation: A literature study on park and ride in the Bandung metropolitan area. MATEC Web of Conferences, 276.

2) Asapa, A. G. (2014). Park and Ride Sebagai Bagian dari Pelayanan Kereta Api Perkotaan Bandung. 17.

3) Banister, D. (2000). Sustainable urban development and transport-a Eurovision for 2020. Transport Reviews, 20(1), 113-130.

4) Buchari, E. (2015). Transportation demand management: A park and ride system to reduce congestion in Palembang city Indonesia. Procedia Engineering, 125, 512-518.

5) Central Bureau of Statistics (BPS). (2019). Regency of Bekasi In Numbers. Bekasi: Central Bureau of Statistics.

6) Central Bureau of Statistics (BPS). (2019). DKI Jakarta Province in Numbers,Jakarta: Central Bureau of Statistics.

7) Darmawan, R., \& Riduansyah, M. (2017). Kepuasan Pengguna Pelayanan Park And Ride di DKI Jakarta (Studi Perbandingan Antara Park and Ride Terminal Ragunan dan Terminal Kampung Rambutan). Jurnal Vokasi Indonesia, 5(1), 14-21.

8) Dijk, M., de Haes, J., \& Montalvo, C. (2013). Park-and-Ride motivations and air quality norms in Europe. Journal of Transport Geography, 30, 149-160.

9) Fajar, I., \& Djunaedi, A. (2020). Factors That Influencing Informal Park and Ride Facility Choice in Indonesia: Case Study of Kendal Regency. Jurnal Ilmiah Universitas Batanghari Jambi, 20(1), 54-59.

10) Ferguson, E. (2018). Travel demand management and public policy. Routledge.

11) FHWA. (n.d.). Transportation Demand Management | Organizing and Planning for Operations-FHWA Office of Operations. Retrieved February 26, 2021, from https://ops.fhwa.dot.gov/plan4ops/trans_demand.htm

12) Gilbert, R., \& Tanguay, H. (2000). Sustainable transportation performance indicators project. Brief Review of Some Relevant Worldwide Activity and Development of an Initial Long List of Indicators, The Centre for Sustainable Transportation, Toronto, Ontario, Canada.

13) Indah, F., Susantono, B., \& Riyanto, B. (2015). Analisis Tingkat Pelayanan Transportasi Berkesinambungan (Seamless Service) (Studi Kasus: Perjalanan Komuter Jabodetabek melalui Stasiun Kereta Api Bekasi). 15.

14) Lam, W. H., Holyoak, N. M., \& Lo, H. P. (2001). How park-and-ride schemes can be successful in Eastern Asia. Journal of Urban Planning and Development, 127(2), 6378.

15) Liu, J., Yi, Y., \& Wang, X. (2020). Exploring factors influencing construction waste reduction: A structural equation modeling approach. Journal of Cleaner Production, 276, 123185. https://doi.org/10.1016/j.jclepro.2020.123185

16) Marshall, S., \& Banister, D. (2000). Travel reduction strategies: Intentions and outcomes. Transportation Research Part A: Policy and Practice, 34(5), 321-338. 
17) Ministry of Environment, 2009. Cities at Crossroads: Guidelines for Designing Emission control strategies from the Road Transport Sector in Urban Areas. Jakarta: Kemenneg LH

18) Nazalaputra, M. F., \& Handayeni, K. D. M. E. (2017). Penentuan Faktor-Faktor Pemilihan Park \& Ride Sebagai Fasilitas Pergerakan Komuter Pada Koridor BekasiJakarta. Jurnal Teknik ITS, 6(1), 6-11. https://doi.org/10.12962/j23373539.v6i1.22148

19) Nusraningrum, D., \& Isibhi, F. (2013). The Influence of Kiss and Ride and Park and Ride in Decreasing the Private Transportation by Using the Public Transportation "Transjakarta." 17.

20) Palupiningtyas, S. E. (2015). Kriteria Fasilitaspark And Ride Sebagai Pendukung Angkutan Umum Massal Berbasis Jalan. Warta Penelitian Perhubungan, 27(2), 69. https://doi.org/10.25104/warlit.v27i2.768

21) Parkhurst, G., \& Meek, S. (2014). The effectiveness of park-and-ride as a policy measure for more sustainable mobility. In Parking issues and policies. Emerald Group Publishing Limited.

22) Safitri, R., Sebhatu, S. P., \& Priyanto, S. (2015). Integrated Transport System Toward Sustainable Travel Behavior. 10.

23) Sembiring, J. (2015). Skema Park and Ride di Jakarta (Pembelajaran dari Singapura) Park and Ride Scheme in Jakarta (Lesson Learn From Singapore). 17, 14.

24) Shen, X., Chen, F., Su, B., Chen, Q., \& Yao, J. (2017). Optimization of park-and-ride system: A case study of Shunyi in Beijing. Advances in Mechanical Engineering, 9(8), 1687814017714987.

25) Suryandari, M., Wisakcono, A., \& Agustin, I. W. (2015). Penerapan Park and Ride di Stasiun Bekasi. TATALOKA, 17(3), 172. https://doi.org/10.14710/tataloka.17.3.172185

26) Vincent, M. (2007). Park and ride: Characteristics and demand forecasting.

27) Ying, H., \& Xiang, H. (2009). Study on influence factors and demand willingness of Park and Ride. 2009 Second International Conference on Intelligent Computation Technology and Automation, 4, 664-667. 